\title{
SAMOREGULUJĄCY SIĘ RYNEK I FIKCYJNE TOWARY: PRACA, ZIEMIA I PIENIĄDZ
}

Karl Polanyi

Przedstawiony wyżej ogólny zarys systemów ekonomicznych i historii rynków pokazuje, że do naszych czasów rynki nigdy nie były niczym więcej, niż dodatkami do życia gospodarczego. $Z$ reguly system ekonomiczny stanowił część systemu społecznego. Niezależnie od tego, jakie reguły dominowały w gospodarce, obecność modelu rynkowego pozostawała z nimi w zgodzie. Zasada wymiany czy handlu wymiennego, leżąca u podłoża tego modelu, nie wykazywała tendencji do rozwoju kosztem pozostałych. Tam, gdzie rynki były najbardziej rozwinięte - jak w przypadku merkantylizmu - kwitły one pod kontrolą scentralizowanej administracji, która wzmacniała autarkię zarówno w gospodarstwach chłopskich, jak i w stosunku do życia całego kraju. Regulacja i rynki rozwijały się równolegle. Samoregulujący się rynek nie był jeszcze znany. W rzeczywistości pojawienie się koncepcji samoregulacji stanowiło kompletne odwrócenie istniejących wcześniej tendencji. Jedynie w świetle tych faktów możliwe jest pełne zrozumienie niezwykłych założeń, które dały początek gospodarce rynkowej.

Po pierwsze: gospodarka rynkowa jest systemem ekonomicznym kontrolowanym, regulowanym i sterowanym przez ceny rynkowe. Porządek produkcji i dystrybucji towarów powierzony zostaje samoregulującemu się mechanizmowi. Gospodarka tego typu stanowi wynik założenia, że ludzie dążą do maksymalnie dużych zysków. System ten zakłada istnienie rynków, na których podaż towarów (włącznie z usługami) dostępnych w określonej cenie - będzie równa popytowi. Postuluje obecność pieniądza, który funkcjonuje w rękach swoich właścicieli jako siła nabywcza. Produkcja jest zatem kontrolowana przez ceny - zyski osób, które nią kierują, będą od owych cen zależały. Także dystrybucja towarów zależy od cen - tworzą one dochody, a z pomoca tych dochodów wyprodukowane towary sa dystrybuowane pomiędzy członków społeczeństwa. Porządek produkcji i dystrybucji towarów jest zatem gwarantowany wyłącznie przez ceny. 
Samoregulacja prowadzi do sytuacji, w której produkcja zostaje przeznaczona na sprzedaż na rynku i wszystkie zyski pochodzą właśnie z takiej sprzedaży. Istnieją zatem rynki zbytu na wszystkie elementy przemysłu, nie tylko na towary (zawsze włącznie z usługami), ale także na pracę, ziemię i pieniądz. Ceny nazywane są tu odpowiednio cenami towarów, płacami, czynszem oraz odsetkami. Przytoczone terminy wskazuja, że ceny generuja dochody: odsetki są ceną za wykorzystywanie pieniądza i tworzą dochody tych, którzy ów pieniądz zapewniaja; czynsz to opłata za korzystanie z ziemi - generuje dochód tych, do których ta ziemia należy; płace to wynagrodzenie siły roboczej - w ten sposób kształtują się dochody osób sprzedających pracę; wreszcie ceny towarów częściowo generują dochody tych, którzy sprzedają swoja przedsiębiorczość - dochód określany jako zysk jest tu w rzeczywistości różnicą między ceną wyprodukowanych towarów a ich kosztem, czyli ceną elementów niezbędnych do ich produkcji. Jeżeli te warunki sa spełnione, wszystkie zyski pochodzą ze sprzedaży na rynku i będą wystarczająco wysokie, żeby wszystkie wyprodukowane towary mogły zostać kupione.

Kolejny zbiór założeń dotyczy państwa i jego polityki. Nic nie ma prawa hamować tworzenia rynków, a dochodom nie można pozwolić, by generowane były w inny sposób, niż poprzez sprzedaż. Nie powinno być jakichkolwiek ingerencji w proces regulacji cen w stosunku do przekształceń warunków rynkowych - niezależnie od tego, czy chodzi o ceny towarów, pracy, ziemi czy pieniądza. Muszą zatem istnieć rynki zbytu na wszystkie elementy przemysłu. Nie mogą być też tolerowane żadne rozwiązania ani decyzje polityczne, które wpływałyby na funkcjonowanie tych rynków. Ani cena, ani popyt, ani podaż nie powinny podlegać zewnętrznym regulacjom czy ustaleniom. Dopuszczalna jest tylko taka polityka i takie środki, które pomagają zapewnić samoregulację rynku poprzez zapewnienie warunków, które uczynia go jedyną siłą organizującą sferę ekonomiczną ${ }^{1}$.

By w pełni zrozumieć, co niosą ze sobą te założenia, wróćmy na chwilę do merkantylizmu i rynków krajowych. W czasach feudalizmu i systemu cechowego ziemia i praca stanowiły część organizacji społecznej (instytucja pieniądza jeszcze nie była wówczas na tyle rozwinięta, by stać się istotną częścią przemysłu). Ziemia, centralny element porządku feudalnego, stanowiła podstawę systemu militarnego, sądowego, administracyjnego i politycznego. Jej status i funkcje określane były przez przepisy prawne oraz prawo zwyczajowe. Czy posiadaną ziemię można przekazywać, a jeśli tak, to komu i na jakich warunkach? Co pociaga za sobą prawo własności?

\footnotetext{
${ }^{1}$ H.D. Henderson. Supply and Demand. 1922. Rynek ma podwójną funkcję: rozdział czynników pomiędzy różne metody ich wykorzystania oraz organizacja sił wpływających na ogólną podaż owych czynników.
} 
Do czego można wykorzystywać określone typy ziemi - wszystkie te kwestie były wyłączone z organizacji kupna i sprzedaży. Określał je zupełnie inny zbiór przepisów instytucjonalnych.

To samo dotyczyło organizacji pracy. W systemie cechowym - podobnie jak w każdym innym wcześniejszym systemie ekonomicznym - motywy i okoliczności aktywności produkcyjnej były częścią ogólnej organizacji społeczeństwa. Relacje mistrza, czeladnika i terminatora, warunki pracy, liczba terminatorów, płace robotników - wszystkie te elementy regulował obyczaj i przepisy cechu oraz miasta. Merkantylizm jedynie ujednolicił te zasady albo za pomocą ustawy - jak w Anglii - albo poprzez „nacjonalizację” cechów, jak we Francji. Feudalny status ziemi został zniesiony jedynie w takim stopniu, w jakim związany był z lokalnymi przywilejami. W innych kwestiach ziemia pozostała extra commercium zarówno w Anglii, jak i we Francji. Do czasu Wielkiej Rewolucji 1789 r. własność ziemska pozostawała źródłem przywilejów społecznych we Francji; nawet w późniejszym okresie w Anglii prawo zwyczajowe dotyczące ziemi było w zasadzie średniowieczne. Merkantylizm, przy wszystkich swoich tendencjach do komercjalizacji, nigdy nie uderzał w zabezpieczenia, chroniące te dwa podstawowe czynniki produkcji - pracę i ziemię - przed tym, by stały się przedmiotami handlu. W Anglii ustawodawstwo wdrażające „upaństwowienie” pracy za pośrednictwem Ustawy o ręemiośle (1563) oraz prawa ubogich (1601) wyłączyło pracę ze strefy zagrożenia, a prowadzona przez Tudorów i na początku rządów Stuartów walka z grodzeniem pól stanowiła konsekwentny protest przeciw nastawionej na zysk eksploatacji własności ziemskiej.

To, że merkantylizm - niezależnie od nacisku, jaki kładł na komercjalizację w polityce krajowej - traktował rynki w sposób dokładnie odwrotny niż gospodarka rynkowa, najlepiej pokazuje szeroko zakrojona ingerencja państwa w przemysł. W tej kwestii nie istniała żadna różnica między zwolennikami merkantylizmu a feudalizmu, centralizującymi biurokratami a konserwatywnymi partykularystami. Dzieliła ich głównie ocena metod regulacji: cechy, miasta i prowincje odwoływały się do siły obyczaju i tradycji, natomiast nowa władza państwowa opowiadała się za ustawami i rozporządzeniami. Wszyscy byli jednak w tym samym stopniu przeciwni idei komercjalizacji pracy i ziemi - stanowiącej warunek konieczny gospodarki rynkowej. Cechy i przywileje feudalne zostały we Francji zniesione dopiero w 1790 r., w Anglii ustawe o rzemiośle uchylono dopiero w latach 1813-1814, a wprowadzone w czasie rządów Elżbiety I prawo ubogich - w 1834 r. Przed ostatnim dziesięcioleciem XVIII w. w żadnym z tych krajów nie rozważano nawet możliwości stworzenia wolnego rynku pracy. Koncepcja samoregulacji życia gospodarczego znajdowała 
się całkowicie poza horyzontem ówczesnych wyobrażeń. Merkantylista koncentrował się na rozwoju krajowych zasobów - włącznie z dążeniem do pełnego zatrudnienia - za pośrednictwem handlu. Tradycyjną organizację ziemi i pracy uważał za oczywistą. Pod tym względem był równie daleki od dzisiejszych koncepcji, jak daleki był w dziedzinie polityki - tutaj jego wiary $\mathrm{w}$ absolutną władzę oświeconego despoty nie hamowały żadne przeczucia demokracji. I podobnie jak przejście do demokracji i systemu przedstawicielskiego pociagało za sobą całkowite odwrócenie tendencji epoki, tak i przejście od rynków regulowanych do rynków samoregulujących się, które nastąiło pod koniec XVIII w., stanowiło kompletną transformację struktury społeczeństwa.

Samoregulujący się rynek wymaga instytucjonalnego podziału społeczeństwa na sferę gospodarczą i polityczną. W istocie, taka dychotomia jest - z punktu widzenia społeczeństwa jako całości - jedynie potwierdzeniem istnienia samoregulującego się rynku. Można by twierdzić, że rozdział tych dwóch sfer obowiązywał w każdym typie społeczeństwa w całej naszej historii. Taki wniosek byłby jednak oparty na błędnym rozumowaniu. Istotnie, żadne społeczeństwo nie może istnieć bez pewnego rodzaju systemu, który gwarantuje porządek w sferze produkcji i dystrybucji towarów. Nie oznacza to jednak, że muszą istnieć odrębne, powołane tylko w tym celu instytucje. Zwykle ład gospodarczy stanowi jedynie funkcję ładu społecznego. Ani w warunkach plemiennych, ani feudalnych, ani w doktrynie merkantylizmu nie istniał w społeczeństwie - jak już się przekonaliśmy - odrębny system ekonomiczny. Dziewiętnastowieczne społeczeństwo, w którym działalność gospodarcza była wyizolowana i podporządkowana szczególnej motywacji ekonomicznej, stanowiło pod tym względem nadzwyczajny zwrot.

Taki model instytucjonalny nie mógłby funkcjonować, gdyby społeczeństwo nie było podporządkowane jego wymogom. Gospodarka rynkowa może istnieć jedynie w społeczeństwie rynkowym. Do tej ogólnej konkluzji doszliśmy wcześniej, analizując sam model rynkowy. Teraz możemy określić nieco bardziej precyzyjnie przyczyny skłaniające nas do takiego twierdzenia. Gospodarka rynkowa musi obejmować wszystkie czynniki przemysłu, włącznie z praca, ziemią i pieniądzem. (W takiej gospodarce także pieniądz stanowi kluczowy element życia przemysłowego, a jego włączenie w mechanizm rynkowy ma - jak się przekonamy - daleko idące konsekwencje natury instytucjonalnej). Jednak praca i ziemia nie są niczym innym, niż ludźmi, tworzącymi każde społeczeństwo, oraz naturalnym otoczeniem, w których oni funkcjonują. Włączenie ich w mechanizm rynkowy oznacza podporządkowanie samej istoty społeczeństwa prawom rynku.

Możemy obecnie omówić bardziej szczegółowo instytucjonalną naturę gospodarki rynkowej oraz zagrożenia, jakie niesie ona dla społeczeństwa. 
Najpierw opiszemy metody, za pomocą których mechanizmowi rynkowemu umożliwia się kontrolę nad elementami życia przemysłowego, następnie zaś spróbujemy ocenić skalę i wpływ tego mechanizmu na społeczeństwo, które poddane jest jego działaniu.

Mechanizm rynkowy przystosowuje się do różnego rodzaju czynników życia przemysłowego dzięki koncepcji towarów. Towary są tu definiowane empirycznie jako przedmioty wyprodukowane po to, by zostać sprzedane na rynku. Rynki określa się z kolei - także w empiryczny sposób - jako rzeczywiste kontakty pomiędzy kupującymi a sprzedającymi. W związku z tym każdy element przemysłu uważa się za wyprodukowany na sprzedaż - dopiero wtedy zaczyna on podlegać mechanizmowi podaży i popytu. W praktyce oznacza to, że muszą istnieć rynki zbytu na wszystkie elementy przemysłu, że w ramach tych rynków każdy z elementów zorganizowany jest w ramach mechanizmu podaży i popytu, i że ma cenę, która wchodzi $\mathrm{w}$ interakcje z popytem i podaża. Te niezliczone rynki są ze soba połączone i tworza Jeden Wielki Rynek².

Sednem przedstawionej wyżej koncepcji jest następujące założenie: praca, ziemia i pieniądz to kluczowe elementy przemysłu. Także i one muszą być zorganizowane w rynki. W istocie, te rynki stanowią absolutnie podstawową część systemu ekonomicznego. Jednak w rzeczywistości praca, ziemia i pieniądz towarami nie są. W żadnym wypadku nie można do nich odnieść twierdzenia, które mówi, że wszystko, co jest sprzedawane i kupowane, musiało zostać wyprodukowane na sprzedaż. Innymi słowy, w perspektywie empirycznej definicji towarów - nie są one towarami. Praca określa jedynie ludzka aktywność, która nie jest inicjowana z myśla o sprzedaży - procesem tym powodują zupełnie inne przyczyny - ponadto nie można jej oddzielić od pozostałych elementów ludzkiego życia, nie można jej też przechować czy zmobilizować. Ziemia to z kolei inna nazwa natury, niebędącej przecież wytworem człowieka. Pieniądz - w rozumieniu materialnym - stanowi znak siły nabywczej, która z reguły wcale nie jest produkowana, ale powstaje za pośrednictwem mechanizmu bankowości czy finansów publicznych. Żaden z tych elementów nie powstaje z myślą o sprzedaży. Dlatego też używanie kategorii towaru w odniesieniu do pracy, ziemi i pieniądza - to czysta fikcja.

Niemniej jednak dzięki tej fikcji zostały zorganizowane rynki pracy, ziemi i pieniądza ${ }^{3}$. Ich podaż i popyt zyskuja charakter rzeczywistych wartości, a jakiekolwiek kroki czy rozwiązania, które blokowałyby tworzenie

\footnotetext{
${ }^{2}$ G.R. Hawtrey, tamże. Hawtrey uważa, że funkcja takiego rynku polega na czynieniu „rynkowej wartości względnej wszystkich towarów wzajemnie spójną".

${ }^{3}$ Twierdzenie Marksa o fetyszowym charakterze wartości towarów odnosi się do wartości wymiennej prawdziwych towarów i nie ma nic wspólnego z towarami fikcyjnymi, o których mowa w tekście.
} 
takich rynków, w naturalny sposób zagrażałyby samoregulacji systemu. Fikcja towarowa dostarcza zatem podstawowej zasady, organizującej całe społeczeństwo. Ma ona duży i wielowymiarowy wpływ na prawie wszystkie jego instytucje. Zgodnie z tą zasadą nie mogą istnieć żadne ustalenia czy działania, które mogłyby przeszkodzić funkcjonowaniu mechanizmu rynkowego, opierającego się na fikcji towarowej.

Taki postulat nie może być utrzymany w mocy w odniesieniu do pracy, ziemi i pieniądza. Przyzwolenie na to, by losem ludzkim i otoczeniem człowieka kierował jedynie mechanizm rynkowy, spowodowałoby rozpad społeczeństwa. „Siła robocza” fikcyjnego towaru nie może być bowiem przenoszona, ślepo wykorzystywana czy nawet pozostawiana samej sobie bez wpływu na człowieka, który jest akurat właścicielem owego dziwnego towaru. Pełna kontrola nad siłą robocza, reprezentowaną przez danego człowieka, pozwalałaby systemowi jednocześnie rozporządzać psychiczna i moralna istota człowieka. Pozbawiony warstwy ochronnej, jaką stanowia wytworzone przez kulturę instytucje, zginąłby on wskutek społecznego obnażenia. Stałby się tym samym ofiarą przejmującej społecznej destabilizacji, której emanacjami byłyby występek, perwersja, zbrodnia i śmierć głodowa. Natura zostałaby zredukowana do swoich elementów: krajobrazy skalane, rzeki zanieczyszczone, bezpieczeństwo militarne zagrożone, a możliwość produkcji pożywienia i surowców - zaprzepaszczona. Rynkowa organizacja siły nabywczej okresowo prowadziłaby do likwidacji przedsięwzięć gospodarczych, bowiem braki i nadwyżki pieniądza okazałyby się dla nich równie katastrofalne w skutkach, co powodzie i susze w społeczeństwach prymitywnych. Nie ulega wattpliwości, że rynki pracy, ziemi i pieniądza s a kluczowe w gospodarce rynkowej. Jednak żadne społeczeństwo nie wytrzymałoby - nawet przez krótki czas - skutków systemu opartego na tak czystej fikcji, gdyby człowiek i natura, a także organizacja handlu nie były chronione przed spustoszeniami, dokonywanymi przez ów szatański młyn.

Skrajna fikcyjność gospodarki rynkowej opiera się w tym przypadku na tym, że proces produkcji opiera się tu na mechanizmie kupna i sprzedaży. W społeczeństwie komercyjnym niemożliwy jest jakikolwiek inny sposób organizacji produkcji rynkowej ${ }^{4}$. W późnym średniowieczu przeznaczona na eksport produkcja przemysłowa znajdowała się w rękach zamożnego mieszczaństwa i odbywała się pod jego bezpośrednim nadzorem w miastach. Później, w społeczeństwie merkantylnym, produkcję organizowali kupcy i nie była ona już ograniczona wyłącznie do miast. W tym okresie funkcjonował „system nakładczy”, przemysł krajowy zaopatrywali w surowce kupcy-kapitaliści, którzy kontrolowali proces produkcji, stanowiący

${ }^{4}$ W. Cunningham, Economic Change, w: Cambridge Modern History, tom I. 
czysto komercyjne przedsięwzięcie. To właśnie wówczas produkcja przemysłowa znajdowała się w dużym stopniu pod kontrolą kupca. Znał on i rozumial rynek - wiedzial, na jakie produkty istnieje popyt, jaką ma on skalę. Ręczył też za zaopatrzenie - głównie w drewno, indygo i niekiedy elementy dziewiarek wykorzystywanych w chałupnictwie. Jeżeli zaopatrzenie zawiodło, najbardziej dotknięty był właśnie chałupnik, który tracił na pewien czas zatrudnienie. Jednak przy takiej organizacji nie potrzebowano żadnych kosztownych zakładów przemysłowych, a kupiec nie ponosił większego ryzyka, biorąc na swoje barki odpowiedzialność za produkcję. Przez wieki opisywany system umacniał się i rozszerzał swój zasięg; w Anglii, przemysł wełniany - podstawowa branża przemysłu krajowego - opanował ogromne sektory kraju. Ten, kto kupowal i sprzedawal, mimo woli zapewniał też produkcję. Wytwarzanie towarów nie wymagało odwzajemniania darów czy pomocy, towarzyszącego głowie rodziny niepokoju o tych, których potrzeby należało zaspokoić, dumy rzemieślnika $z$ wykonywania własnego zawodu, satysfakcji płynącej z publicznych wyrazów uznania - wystarczyła jedynie żądza zysku, motywacja tak bliska owemu człowiekowi, którego zawód polegał na kupnie i sprzedaży towarów. Do końca XVIII w. produkcja przemysłowa w Europie Zachodniej była tylko jedna z gałęzi ówczesnego handlu.

Dopóki machina ta stanowiła niedrogie i „proste” narzędzie, nie pojawiała się potrzeba wprowadzania w niej jakichkolwiek zmian. Teraz chałupnik mógł - w tym samym czasie - produkować więcej towarów. Wydaje się, że taki stan rzeczy powinien skłaniać go do wykorzystywania maszyn, których użycie pozwalało zwiększyć zarobki. Jednak opisywane tu możliwości nie wpłynęły w istotnym stopniu na organizację produkcji. To, czy tanie maszyny należały do robotnika, czy do kupca, miało do pewnego stopnia znaczenie dla pozycji społecznej obydwu stron i decydowało o wysokości dochodów pracownika - były one wyższe, kiedy używane narzędzia należały do niego. Jednak nie wymagało to od kupca, by stał się kapitalista przemysłowym. Strumień towarów rzadko wysychał. Większe trudności dotyczyły zaopatrzenia w surowce, które z założenia nie mogło mieć charakteru ciagłego. Nawet w takich przypadkach straty poniesione przez kupca, do którego należały maszyny, nie były duże. To nie nadejście maszyny jako takiej, ale powstanie urządzeń o złożonej konstrukcji i zakładów przemysłowych radykalnie przekształciło relację między kupcem a produkcją. Choć nowa organizacja produkcji została wprowadzona właśnie przez kupca - fakt ten wpłynął na cały późniejszy bieg transformacji - wykorzystanie maszyn o złożonej konstrukcji zakładów przemysłowych wymagało rozwinięcia sieci fabryk, tym samym stanowiło decydujacy zwrot. W konsekwencji handel stracił swoja pozycję 
na rzecz przemysłu. Produkcja przemysłowa przestała być jedynie elementem handlu organizowanego przez kupca w ramach mechanizmu kupna i sprzedaży. Stała się ona długoterminową, związaną z ryzykiem inwestycją. Jeżeli ciagłość produkcji nie była zapewniona, takie ryzyko stawało się wręcz niemożliwe do zniesienia.

Jednak im bardziej złożona stawała się produkcja przemysłowa, tym liczniejsze były czynniki, których nie mogło zabraknąć. Trzy spośród nich miały oczywiście kluczowe znaczenie: praca, ziemia i pieniądz. Ich przepływ w społeczeństwie opartym na handlu musiał przyjąć formę kupna. Wprowadzano je zatem na rynek - innymi słowy funkcjonowały jako towary. Rozszerzenie mechanizmu rynkowego na elementy przemysłu - pracę, ziemię i pieniądz - stanowiło nieuchronną konsekwencję wprowadzenia systemu fabryk w społeczeństwie opartym na działalności handlowej. Elementy przemysłu musiały być w sprzedaży.

W tej sytuacji powstała potrzeba stworzenia systemu rynkowego. Wiemy, że w takim systemie dochody zapewnione są jedynie wówczas, gdy samoregulacja zabezpieczona jest przez współzależne rynki konkurencyjne. Ponieważ rozwój systemu fabryk stanowił część procesu kupna i sprzedaży - praca, ziemia i pieniądz musiały zostać przekształcone w towary po to, by zapewnić ciagłość produkcji. Oczywiście w rzeczywistości nie mogły w ten sposób zostać przekształcone w towary, bowiem nie były pierwotnie produkowane z myślą o sprzedaży na rynku. Fikcja, która pozwalała wierzyć, że właśnie takie jest ich przeznaczenie, stała się nadrzędną organizująca społeczeństwo zasadą. Warto zwrócić szczególną uwagę na jeden spośród trzech omawianych tu elementów, a mianowicie skupić się na pracy. Praca to pojęcie techniczne, które w rzeczywistości odnosi się do ludzi (mówimy tutaj o pracownikach, nie o pracodawcach). Od tego czasu organizacja pracy przekształcała się równolegle z organizacja systemu rynkowego. Jednak organizacja pracy jest po prostu innym określeniem, opisującym życie codzienne zwykłych ludzi. Oznacza to, że rozwój systemu rynkowego miał dać początek zmianom w organizacji samego społeczeństwa. W którymś momencie społeczeństwo stało się jedynie dodatkiem do systemu ekonomicznego.

Pamiętamy przedstawioną przez nas paralelę pomiędzy spustoszeniami, dokonanymi przez proces grodzenia pól w Anglii, a katastrofą, która dotknęła społeczeństwo po rewolucji przemysłowej. Udoskonalenia i postęp jak podkreślaliśmy - sa z reguły osiagane kosztem destabilizacji społecznej. Jeżeli tempo owej destabilizacji jest zbyt gwałtowne, zbiorowość musi ulec osłabieniu. Tudorowie i Stuartowie w poczattkach swojego panowania uratowali Anglie przed losem Hiszpanii, regulując tempo przemian w taki sposób, że stało się ono możliwe do udźwignięcia, a jego skutki zostały 
w odpowiedni sposób uregulowane. Nic jednak nie uchroniło prostych ludzi w Anglii przed tragicznymi skutkami rewolucji przemysłowej. Ślepa wiara w spontaniczny postęp zawładnęła ludzkimi umysłami i nawet najbardziej oświecone postaci epoki z niemal religijnym fanatyzmem parly $\mathrm{w}$ stronę bezgranicznych i nieuregulowanych przemian społecznych. Skutki tych działań stały się ogromnym obciążeniem dla zwykłych ludzi. Bez watpienia społeczeństwo zostałoby unicestwione, gdyby nie podjęto decyzji, które osłabiły działanie autodestrukcyjnego mechanizmu.

Historia społeczna XIX w. była zatem konsekwencja podwójnego ruchu: rozszerzeniu organizacji rynkowej i objęciu przez nią rzeczywistych towarów towarzyszyło jej ograniczenie w stosunku do towarów fikcyjnych. Podczas gdy z jednej strony rynki rozrastały się na całym świecie, a liczba oferowanych towarów dynamicznie rosła, cały szereg rozwiązań politycznych regulował funkcjonowanie potężnych instytucji, mających kontrolować oddziaływanie rynku na pracę, ziemię i pieniądz. Podczas gdy organizacja światowych rynków towarowych, kapitałowych i walutowych pod egida waluty złotej nadała niespotykany rozmach mechanizmowi rynkowemu, powołano jednocześnie do życia dobrze umocowany ruch, którego celem było przeciwstawienie się niebezpieczeństwom, jakie wiązały się z gospodarką kontrolowana przez rynek. Społeczeństwo broniło się $\mathrm{w}$ ten sposób przed zagrożeniami, tkwiącymi w samoregulującym się systemie rynkowym.

Przełożyła Maria Zawadzka

/// Samoregulujacy sie rynek i fikcyjne towary: praca, ziemia $i$ pieniadz, w: „Wielka transformacja”, s. 83-92, PWN, Warszawa 2011. Karl Polanyi, The Great Transformation. The Political and Economic of Our Times (C) 1944, 1957, 2001 by Karl Polanyi, copyright (C) for the Polish edition by Wydawnictwo Naukowe PWN S.A. Warszawa 2011. Published with permission of PWN. Dziękujemy za zgodę na opublikowanie przekładu. 